\title{
DEVELOPMENT OF FATTY WASTE COMPOSTING TECHNOLOGY USING BACTERIAL PREPARATION WITH LIPOLYTIC ACTIVITY
}

\author{
Jolanta Aikaitè-Stanaitienè $\dot{ }^{1}$, Saulius Grigiškis ${ }^{2}$, Donatas Levišauskas ${ }^{3}$, \\ Vilma Čipinytè ${ }^{4}$, Egidijus Baškys ${ }^{5}$, Vaiva Kačkytè ${ }^{6}$ \\ 1,4,5 JSC „,Biocentras”, V. Graičiūno g. 10, LT-02241 Vilnius, Lithuania \\ ${ }^{2,6}$ Vilnius Gediminas Technical University, Saulètekio al. 11, LT-10223 Vilnius, Lithuania \\ ${ }^{3}$ Process Control Department, Kaunas University of Technology, Studentu g. 50, LT-51368 Kaunas, Lithuania \\ E-mail: ${ }^{2}$ biocentras@biocentras.lt (corresponding author)
}

Submitted 13 Mar. 2009; accepted 21 Jan. 2010

\begin{abstract}
A new composting technology of waste with high fat content was developed in JSC „Biocentras”. The composting technology of fat-contaminated waste is based on the use of fat-oxidizing microorganisms. Developed technology is commended for cleaner production/pollution prevention approach as well as meets strict environmental and hygiene requirements. The composting process was investigated for the process optimization by applying the response surface methodology. Values of parameters of composting process were monitored in lab-scale composters. The optimal composition of the composing mixture was determined: the initial fat content $-5 \%$, the concentration of bacterial preparation cells $10^{9} \mathrm{CFU} / \mathrm{g}$, the quantity of structural materials $-9.5 \%$. Fat degradation rate slowed down 3 times if the initial fatty concentration increased from $5 \%$ to $20 \%$. Concentrated fatty-waste disposal site prototype was designed. Composting process duration lasted 1 to 1.5 year.
\end{abstract}

Keywords: fats, oils and grease (FOG), composting, bacterial preparation, biodegradation, mathematical modeling, optimization.

\section{Introduction}

Sustainable technologies promote the development of green techniques and products in order to live in clean and healthy environment. New effective waste recycling and utilization technologies are introduced. Our goal is to develop an effective, optimized and affordable technology for recovery of fatty pollutants for meat, fish and oil processing enterprises. At the same time, it will reduce the quantity of biodegradable waste disposed in landfills.

Industrial and household fatty waste can be divided into two categories - "yellow" and "brown" fat. The first category fatty waste can be used for the secondary processing of animal feed additives, production of soaps, oils, cosmetics and skin care products. This type of waste can be composted either. The second type of fat is not recycled and must be handled according to the existing waste management requirements. Biodegradable organic waste of this origin can be incinerated, decayed or composted.

According to the Landfill Directive 1999/31/EC, the State's strategic plan for waste management tasks foresaw the quantity of biodegradable waste that can be disposed in landfills. The plan provides that the amount of waste disposed in landfills must be reduced to $75 \%$ by 2010 compared with 2000; by 2013 - up to $50 \%$; by $2020-$ will have to achieve only $35 \%$ of landfill biodegradable waste compared with 2000 (EC directive 2006).

Biodegradable waste is any waste that may be degraded aerobically or anaerobically, eg., garden waste, paper or cardboard (Navickas et al. 2007). Composting is the waste management method, when the complex of biological, biochemical and physical processes is acting, i.e. microorganisms, soil animals and enzymes mineralize biodegradable waste transforming it to biogenic elements and mold.

Composting is not only a natural environmentfriendly way to reduce organic waste, but also the good way to reuse secondary raw materials or to produce a high-quality product (Das et al. 2002). A number of different composting technologies are created. The basis of those technologies is the homogenization, mixing, good aeration and irrigation of biodegradable waste.

Compost systems can be divided according to the historically ordered composting systems (Haug 2000): 1) open system, without a reactor - the system of composting pile, stationary pile system, 2) reactor systems (tanks or closed) - the vertical compost material spreading, horizontal and inclined compost materials spreading, composting in the box.

Open composting system is the cheapest biodegradable waste treatment method, but it has drawbacks and is not suitable for industrial composting. The use of closed-type equipment is popular in composting of industrial waste. They allow reducing unpleasant smells during the composting process, because the resulting gas is released into environment through the bio-filter or membranes. This type of equipment usually has moisture and oxygen support control monitoring possibility, which allows to regulate and to speed the process. Composting process is divided into two 
phases - intensive degradation (thermophilic) phase and compost maturation. There are no strict borders between these stages, but the first stage is characterized by a large volume of oxygen consumption and high temperatures, and in the maturation stage the oxygen is consumed in smaller quantities, passive ventilation is sufficient.

The organic waste with high fat content typically is not composted. However, during the lipid degradation much more energy is emitted in comparison with the degradation of other organic components such as carbohydrates. Higher energy levels are advantageous in thermophilic processes, where high temperature is desired to reduce pathogenic microorganisms; the chemical reactions take place faster at higher temperatures also. A thermophilic condition causes changes in the physical properties of fat, such as melting point, dispersion and solubility (Agamuthu 1994). Therefore, the fat can be an excellent source for aerobic composting.

Composting of fat waste from food industry processing plants, slaughterhouses, restaurants deal with some problems: low water retention and solubility, lack of porosity and relatively low biodegradability of some fat. A significant negative influence also has the gas resulting from fat degradation: hydrogen sulfur $\left(\mathrm{H}_{2} \mathrm{~S}\right)$, methyl mercaptan $\left(\mathrm{CH}_{3} \mathrm{SH}\right)$, ammonia $\left(\mathrm{NH}_{3}\right)$ and volatile organic compounds. Special biological additives that promote the production of enzymes and fatty waste biodegradation are used in composting systems for the reduction of strong and unpleasant smell of concentrated gas (Gandhi 1997).

An alternative method for composting could be fatty waste neutralization using soluble lipase preparations. However, this technology is expensive, single-use and does not have wide application in practice (Adewumi et al. 2005; Mendes and Castro 2005; Saifuddin and Chuna 2006). Therefore, composting by using bacterial compositions, composed of a mixture of selected microorganism's cultures is more promising and economical method for fatty waste treatment. Microbial strains mixes have strong biodegradation capacity, since the breakdown of complex compounds found in the FOG (fats, oils and greases) waste require genetic information of several organisms. Genetic potential and certain environmental factors such as temperature, $\mathrm{pH}$, and available nitrogen and phosphorus sources determine the speed and extent of biodegradation.

Concentrated fatty waste obtained by mechanical removal, are composted in specially equipped places. These wastes are neutralized using active cultures of microorganisms. In our previous work has shown that the bacterial compositions created by JSC "Biocentras" breakdown effectively the fat in the water and soil and can therefore be applied to speed up composting (Grigiškis et al. 2007). Before composting technology can be commercially adopted, it is necessary to determine the grease-rich wastes decomposition rate, time required to compost and optimal composition of the initial compost mixture. Values of parameters of composting process were monitored in lab-scale composters. Developed technology is attractive for cleaner production/pollution prevention approach, as well as meets strict environmental and hygiene requirements.

\section{Methods and materials}

The fat content, temperature, humidity, $\mathrm{pH}$, total and ammonium nitrogen, phosphorus, total carbon and content of live microorganisms were assessed in compost mixtures during the composting process. The temperature of compost mixtures was measured daily with a digital indicator MASTFCH ${ }^{\circledR}$ MAS838 pinning thermal element to the center of the each reactor. For the determination of humidity $10 \mathrm{~g}$ of composted mixture was dried for 4048 hours in Binder ED 23 (Germany) drying oven in $105{ }^{\circ} \mathrm{C} \pm 1{ }^{\circ} \mathrm{C}$ till the constant weight was reached. For the measurement of the $\mathrm{pH}$, the suspension of $1 \mathrm{M}$ potassium chloride solution in the ratio 1: 2.5 (inoLab 720, Germany) was prepared (LST ISO 10390:2005). Fat was extracted by chloroform-methanol mixture. After extraction chloroform layer was poured to the weighting bottle heated to constant weight, dried and weighted. The fat content calculated by mass difference. The total nitrogen content was determined by the Kjeldahl method (InKjel 625 F, S4 Behr, Behr Labor-Technik). Ammonium nitrogen was determined manually by spectrophotometer by extracting with $2 \mathrm{M}$ potassium chloride solution. The content of phosphorus was determined spectrophotometrically, using ammonium molybdate. Spectrophotometrical measurements were made by Shimadzu UV-1601 spectrophotometer (Shimadzu Corporation). The total carbon content was determined by oxidation of a compost mixture in hot potassium dichromate solution (Alef and Nannipieri 1995).

Fats were biodegraded by using bacterial composition, composed of the active microorganisms Enterobacter aerogenes E13 (capable of degrading fats), Arthrobacter sp. (N3) (capable of degrading aliphatic compounds) and Bacillus coagulans (S1) (capable of degrading complex peptide bounds) cultures. The bacterial strains were cultivated in $750 \mathrm{ml}$ Erlenmeyer flasks with $70 \mathrm{ml}$ of nutrient broth ("Oxoid") separately at $30{ }^{\circ} \mathrm{C}$ and $200 \mathrm{rpm}$. in a rotary shaker (Innova 43, New Brunswick Scientific Co.) for $16 \mathrm{~h}$. The cell count was determined by plating serial dilutions of samples on nutrient agar (Oxoid) plates and incubating at $30{ }^{\circ} \mathrm{C}$ for $24 \mathrm{~h}$ (Alef and Nannipieri 1995). Reaction surface methodology based on factor experimental was used for optimization of technological parameters of fatty waste composting (Montgomery 2001; Myers and Montgomery 2002; Levisauskas et al. 2004). The calculation programs were realized in Matlab/Simulink and the Maple environment.

A new composting technology with high fat content was created (Fig. 1). The composting technology of fat contaminated waste is based on the use of fat oxidating microorganisms. Natural microbiological processes can be accelerated using selected cultures of microorganisms with enhanced activity and facilitating their vital activities. Key features of the proposed composting technology processes are grinding, mixing, incorporation of structural materials and the fertilizer $(\mathrm{N}-\mathrm{P}-\mathrm{K}), \mathrm{pH}$ adjustment of composted mixture, spraying of bacterial composition, irrigation and aeration. 


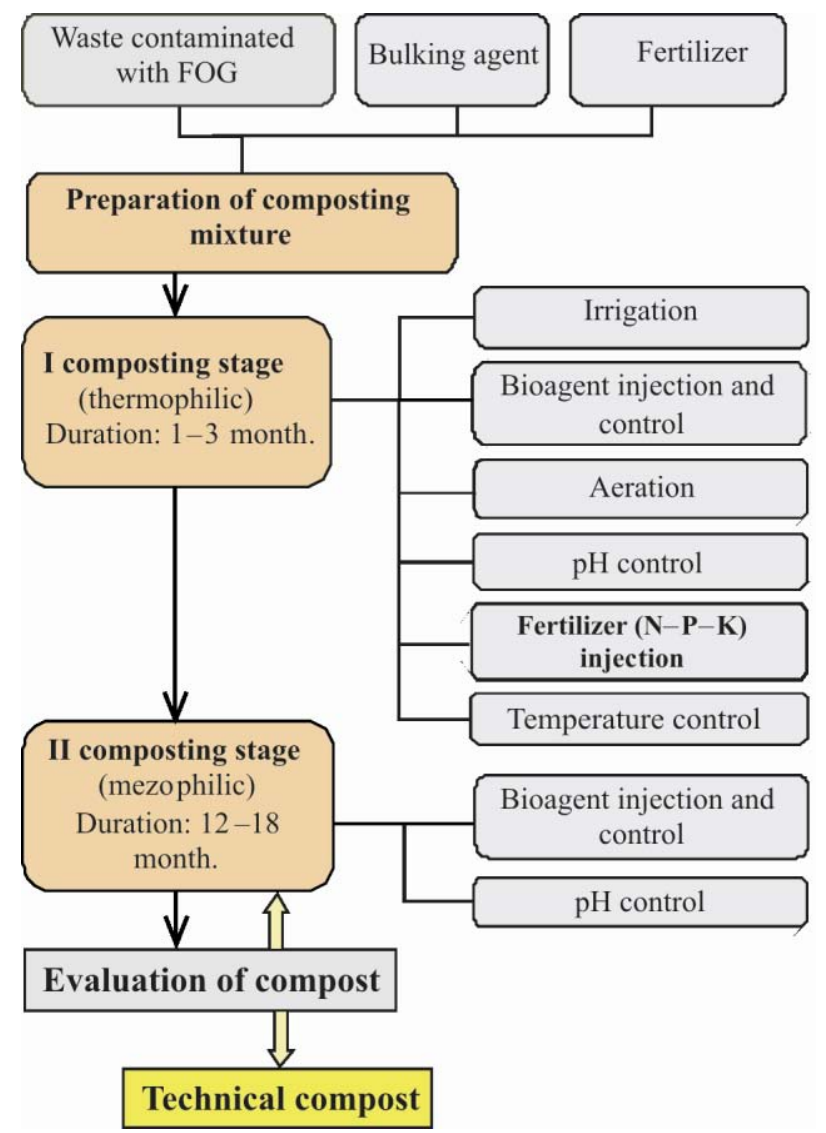

Fig. 1. Composting process diagram

Decanted sewage, collected from the fat traps from meat, fish, vegetable oil processing plants and restaurants and in food preparation businesses have the fat content up to $30-40 \%$. Trapped waste is basically made up of fats and oils.

Saturated and unsaturated fatty acid composition of retained fat varies depending on the company. Retended fat mainly consist of saturated (myristic, palmitic, stearic, eicosanoic, behenic); mono-unsaturated (oleic) and polyunsaturated (linoleic and linolenic) fatty acids (Coker 2006). The degradation of these fatty acid leads to unpleasant smells.

Animal fat consists predominantly of saturated fatty acids, plant's fat - mainly consist of unsaturated fatty acids. These fatty acids are found in all types of grease, only in various amounts. The model grease fatty substrate, made from equal parts of pork fat, beefy suet and sunflower oil, was chosen for composting experiment. The pork fat is made up of saturated palmitic and stearic fatty acids, beef suet mainly consist of saturated palmitic and stearic fatty acids. Pork fat also has a number of oleic acid. Sunflower oil is mostly composed of polyunsaturated linoleic acid and monounsaturated oleic acid (Gunstone and Padley 1997). Thus, practically all the fatty acids forming fatty waste can be found in the model fat mixture.

Appealing on previous research results, we conclude that the degradation takes place effectively when the fat concentration in soil is $5-15 \%$. Above that level fat degradation rates decrease. Similar results were received by
Erhan and Kleiman (1997) Nakasaki (2004) and Gea et al. (2004). Fat degradation increases with increasing time period. In addition, lipid breakdown is dependent on what fatty acids they consist of. The degradation of long chain fatty acids increases with their unsaturation degree and aliphatic chain shortening. It should also be assessed that high concentration of fat has a negative influence on oxygen transport and inhibit the activity of fat-splitting microorganisms (Chipasa and Mędrzycka 2006).

Two series of experiments were carried out for the practical assessment technology being created. The first series of experiments were carried out to assess the initial relationship of the $\mathrm{C} / \mathrm{N}$ ratio and the temperature of composted mixture. Microorganism's (bacteria, fungi and actinomycetes) content also affects the temperature evolution of composted mixture during the process.

Three composting mixes were prepared and the process was carried out in the 20-liter reactors in the optimal composting conditions recommended by literature (Haug 2000; Bazrafshan et al. 2006). The initial concentration of model fat in compost mixtures was (weight ratio) 5\%, soil $-40 \%$, peat $-10 \%$, bacterial compositions $-5 \%$, humidity $-40 \%, \mathrm{pH} 6.8, \mathrm{C} / \mathrm{N}$ ratio was $30 / 1,40 / 1$ and $60 / 1$. C/N ratio was corrected by adding urea to compost mixtures. The temperature of compost mixtures was measured every day.

Three experiments in 20-liter reactors with compost mixtures were carried out in the second series, to choose more correct values of technological parameters which had to be varied in experimental design. Compost mixtures composition is shown in Table 1. Soil and peat were used air-dry. The first compost reactor was supplied with the air at the rate of $0.1 \mathrm{l} / \mathrm{min}$ for aerobic composting conditions assurance. Compost mixes in the $2^{\text {nd }}$ and $3^{\text {rd }}$ reactors were ventilated naturally during the entire composting process. Compost mixtures were investigated after 2, 4, 8 and 12 weeks. The temperature of composting mixtures was measured in all the reactors every day.

Table 1. Composition of composting mixture

\begin{tabular}{l|c|c|c}
\hline Compost composition & $\begin{array}{c}\text { Reactor } \\
1\end{array}$ & $\begin{array}{c}\text { Reactor } \\
2\end{array}$ & $\begin{array}{c}\text { Reactor 3 } \\
\text { (control) }\end{array}$ \\
\hline Fatty substrate, \% & 10 & 10 & 10 \\
\hline Moisture, \% & 35 & 35 & 40 \\
\hline Soil, \% & 40 & 40 & 50 \\
\hline Peat, \% & 10 & 10 & - \\
\hline Bacterial preparation, \% & 5 & 5 & - \\
\hline CaO, \% & 0.12 & 0.12 & 0.12 \\
\hline Fertilizer, \% & 0.1 & 0.1 & - \\
\hline
\end{tabular}

The third series of experiments was carried out to determine the optimal composting conditions of the fat contaminated soil. The goal of optimization was to determine the composition of composting mixture: the quantities of fat, structural materials and bacterial composition, at which the maximum rate of fat degradation is gained. The composting process proceeded in 16 compost boxes with the natural ventilation. Close to D-optimal $\left(\mathrm{B}_{3}\right)$ factorial experimental design (Hartmann et al. 1974) is shown in Table 2. The manipulated factors were: 
$\mathrm{X}_{1}$ - percentage of fat mixture $(5-20 \%), \mathrm{X}_{2}$ - cell concentration of bacterial composition $\left(10^{7}-10^{9} \mathrm{CFU} / \mathrm{g}\right) ; \mathrm{X}_{3}-$ percentage of peat $(5-15 \%)$.

The following technological parameters were fixed during the composting process: temperature $-20 \pm 1{ }^{\circ} \mathrm{C}$; pH 6-7; the quantity of added fertilizer $\left(\mathrm{NH}_{4} \mathrm{NO}_{3}\right.$. $\mathrm{KH}_{2} \mathrm{PO}_{4}$ ) reduced the initial $\mathrm{C} / \mathrm{N}$ ratio to $60 / 1$; compost mixtures humidity was $50-65 \%$. As with all forms of life involved in the composting process microorganisms needed water. Optimal initial moisture content in composted mixture was 50-65\% (Haug 2000; Chipasa and Mędrzycka 2006). With more moisture content, water can fill the pores, and create the conditions for anaerobic composting. Compost boxes were covered with permeable membrane. The temperature of compost mixtures was measured every day (Tremier et al. 2004). The additional microorganism culture was sprayed after the $3^{\text {rd }}$ and $6^{\text {th }}$ week. Analysis was performed after 2, 4, 6, 8 and 16 weeks.

Table 2. Experimental design for 16 composting boxes

\begin{tabular}{c|c|c|c|c|c|c}
\hline \multirow{2}{*}{$\begin{array}{c}\text { Box } \\
\text { No. }\end{array}$} & \multicolumn{3}{|c}{ Exsperiment conditions (factor values) } \\
\cline { 2 - 7 } & \multicolumn{2}{|c|}{$\mathrm{X}_{1}$} & \multicolumn{2}{c}{$\mathrm{X}_{2}$} & \multicolumn{2}{c}{$\mathrm{X}_{3}$} \\
\cline { 2 - 7 } & code & $\begin{array}{c}\text { real, } \\
\%\end{array}$ & code & $\begin{array}{c}\text { real, } \\
\text { CFU/g }\end{array}$ & code & $\begin{array}{c}\text { real, } \\
\%\end{array}$ \\
\hline 1 & +1 & 20 & +1 & $10^{9}$ & +1 & 15 \\
\hline 2 & -1 & 5 & +1 & $10^{9}$ & +1 & 15 \\
\hline 3 & +1 & 20 & -1 & $10^{7}$ & +1 & 15 \\
\hline 4 & -1 & 5 & -1 & $10^{7}$ & +1 & 15 \\
\hline 5 & +1 & 20 & +1 & $10^{9}$ & -1 & 5 \\
\hline 6 & -1 & 5 & +1 & $10^{9}$ & -1 & 5 \\
\hline 7 & +1 & 20 & -1 & $10^{7}$ & -1 & 5 \\
\hline 8 & -1 & 5 & -1 & $10^{7}$ & -1 & 5 \\
\hline 9 & +1 & 20 & 0 & $10^{8}$ & 0 & 10 \\
\hline 10 & -1 & 5 & 0 & $10^{8}$ & 0 & 10 \\
\hline 11 & 0 & 12.5 & +1 & $10^{9}$ & 0 & 10 \\
\hline 12 & 0 & 12.5 & -1 & $10^{7}$ & 0 & 10 \\
\hline 13 & 0 & 12.5 & 0 & $10^{8}$ & +1 & 15 \\
\hline 14 & 0 & 12.5 & 0 & $10^{8}$ & -1 & 5 \\
\hline 15 & 0 & 12.5 & 0 & $10^{8}$ & 0 & 10 \\
\hline 16 & 0 & 12.5 & 0 & $10^{8}$ & 0 & 10 \\
\hline
\end{tabular}

\section{Experimental results}

\subsection{Evaluation of bacterial preparation for composting}

The first series of experiments was carried out to evaluate the relationship between compost $\mathrm{C} / \mathrm{N}$ ratio and temperature (Fig. 2). As the bacteria were breaking down the materials in the compost mixtures, heat was generated and the composts heats up. The temperature changes during the composting process depend not only on the initial $\mathrm{C} / \mathrm{N}$ ratio, but on the nature of the composted material, the method of composting and compost humidity also. C/N ratio is about $30 / 1$ in ideal composting conditions. The constant temperature rise at the presence of recommended $\mathrm{C} / \mathrm{N}$ ratio (Fig. 2), the maximum is reached in the $11^{\text {th }}$ day $\left(71^{\circ} \mathrm{C}\right)$. When the $\mathrm{C} / \mathrm{N}$ ratio is $60 / 1$ the temperature rises slower and settles at $30{ }^{\circ} \mathrm{C}$ for longer time. Microorganisms presenting in the bacterial composition are mezophiles, so this temperature range ensures optimum conditions for their vital functions.

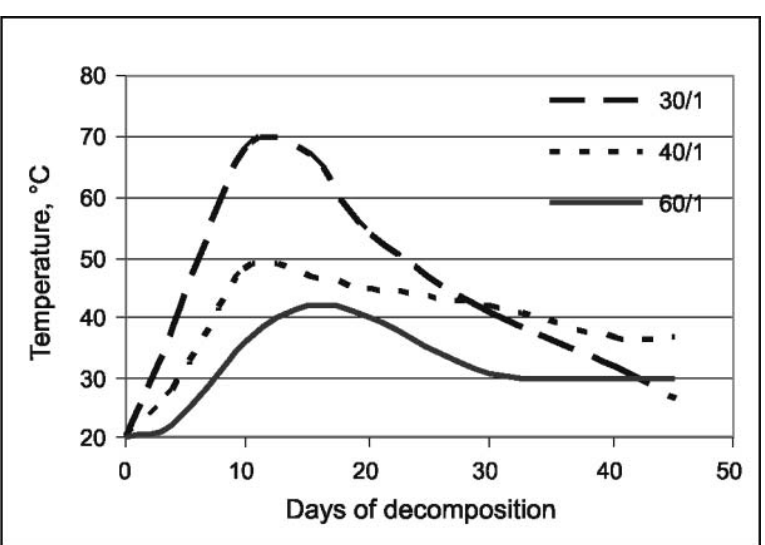

Fig. 2. $\mathrm{C} / \mathrm{N}$ ratio influence of composted mixture temperature

High $\mathrm{C} / \mathrm{N}$ ratio shows the lack of nitrogen needed for the optimal growth of microorganism's population. In this case, biodegradation proceeds in relatively low temperatures and not all the organic waste containing carbon is degraded; the process is very slow also. Biological degradation of organic pollutants consists of two processes: the growth of microorganisms and co-metabolism. During the growth of microorganisms organic pollutants are used as the sole carbon and energy source, nitrogen is used for the protein synthesis. It is therefore necessary to maintain a balanced ratio of these elements in a compost mixture.

Biological degradation of fatty waste is complicated by the physical and chemical properties such as their hydrophobisity (insolubility in water). Therefore microorganisms meet difficulties in access and assimilation of fatty wastes. Fatty compounds are different in structures and levels of solubility, therefore enzymes catalyzing fat degradation reactions meet problems in reaching them. Biological degradation of such waste in thermophilic $\left(50-60^{\circ} \mathrm{C}\right)$ conditions is more appropriate than in mezophilic conditions. However, $\mathrm{C} / \mathrm{N}$ ratio is maintained in high level and the temperature rise relatively slowly at high concentration of fatty substances, therefore the optimal composting proceed at mezophilic conditions (30$\left.37^{\circ} \mathrm{C}\right)$. The destruction of pathogens at high temperature has to be ensured after this stage. In general, nonsporeforming bacteria and vegetative cells or sporulating bacteria are practically destroyed in 5 to $10 \mathrm{~min}$ at temperatures of $60-70{ }^{\circ} \mathrm{C}$ (moist heat). Composting process management is one of the key factors that lead to weed seeds, disease causing microorganisms and pathogens destruction (Haug 2000).

The initial $\mathrm{C} / \mathrm{N}$ ratio in composting mixtures was 94 to 101 (Table 3 ) in the second series of experiments. Fertilizer was added in the $1^{\text {st }}$ and to the $2^{\text {nd }}$ composting reactors to reduce this ratio till $60 / 1$. The optimum moisture content for composting is 55-65\%, but the first week of composting it was difficult to ensure the proper moisture content because of the fat properties to repel water. During the composting process moisture retention was improving. The temperature of environment and compost mixture was registered each day (Fig. 3). The temperature rose to $35^{\circ} \mathrm{C}$ in the first reactor with air supply after 5 days of composting. The temperature in the reactor 
Table 3. Composting results of model fatty pollutant

\begin{tabular}{|c|c|c|c|c|c|c|}
\hline \multirow{2}{*}{$\begin{array}{l}\text { Reactor } \\
\text { No. }\end{array}$} & \multirow{2}{*}{ Measured parameter* } & \multicolumn{5}{|c|}{ Composting time, weeks } \\
\hline & & 0 & 2 & 4 & 8 & 12 \\
\hline \multirow[t]{8}{*}{1} & FOG, $\%$ & $\overline{10.0}$ & 8.12 & 4.10 & 2.81 & 0.54 \\
\hline & Moisture, $\%$ & 42.8 & 45.3 & 43.8 & 48.6 & 46.9 \\
\hline & $\mathrm{NH}_{4}^{+}-\mathrm{N}, \mathrm{mg} / \mathrm{kg}$ & 450.3 & 191.1 & 129.4 & 38.6 & 21.5 \\
\hline & $\begin{array}{l}\text { Total nitrogen }(\mathrm{N}) \text {, } \\
\mathrm{mol} / \mathrm{kg}\end{array}$ & 0.16 & - & - & - & 0.70 \\
\hline & Carbon $(\mathrm{C}), \mathrm{mol} / \mathrm{kg}$ & 16.2 & - & - & - & 13.0 \\
\hline & $\mathrm{C} / \mathrm{N}$ ratio & $101 \rightarrow 60$ & - & - & - & 18.6 \\
\hline & $\mathrm{PO}_{4}^{3-}-\mathrm{P}, \mathrm{mg} / \mathrm{kg}$ & 580.3 & 281.7 & 203.6 & 91.5 & 78.2 \\
\hline & $\mathrm{pH}$ & 7.01 & 5.54 & 5.26 & 6.55 & 6.02 \\
\hline \multirow[t]{8}{*}{2} & FOG, $\%$ & 10.0 & 8.62 & 5.02 & 3.04 & 1.68 \\
\hline & Moisture, $\%$ & 40.5 & 44.9 & 45.6 & 49.2 & 48.3 \\
\hline & $\mathrm{NH}_{4}^{+}-\mathrm{N}, \mathrm{mg} / \mathrm{kg}$ & 450.3 & 240.5 & 136.7 & 113.1 & 98.7 \\
\hline & $\begin{array}{l}\text { Total nitrogen }(\mathrm{N}) \text {, } \\
\mathrm{mol} / \mathrm{kg}\end{array}$ & 0.16 & - & - & - & 0.42 \\
\hline & Carbon (C), mol $/ \mathrm{kg}$ & 16.2 & - & - & - & 14.2 \\
\hline & $\mathrm{C} / \mathrm{N}$ ratio & $101 \rightarrow 60$ & - & - & - & 33.7 \\
\hline & $\mathrm{PO}_{4}^{3-}-\mathrm{P}, \mathrm{mg} / \mathrm{kg}$ & 580.1 & 448.3 & 316.7 & 148.0 & 105.2 \\
\hline & $\mathrm{pH}$ & 7.06 & 5.79 & 5.58 & 6.70 & 5.90 \\
\hline \multirow[t]{8}{*}{3} & FOG, $\%$ & 10.0 & 8.90 & 8.06 & 6.93 & 6.21 \\
\hline & Moisture, $\%$ & 38.9 & 42.8 & 46.3 & 45.2 & 40.4 \\
\hline & $\mathrm{NH}_{4}^{+}-\mathrm{N}, \mathrm{mg} / \mathrm{kg}$ & 40.2 & 36.3 & 33.5 & 24.7 & 20.4 \\
\hline & $\begin{array}{l}\text { Total nitrogen }(\mathrm{N}) \text {, } \\
\mathrm{mol} / \mathrm{kg}\end{array}$ & 0.121 & - & - & - & 0.14 \\
\hline & Carbon (C), $\mathrm{mol} / \mathrm{kg}$ & 11.4 & - & - & - & 8.42 \\
\hline & $\mathrm{C} / \mathrm{N}$ ratio & 94.3 & - & - & - & 60.1 \\
\hline & $\mathrm{PO}_{4}^{3-}-\mathrm{P}, \mathrm{mg} / \mathrm{kg}$ & 50.30 & 46.0 & 28.7 & 23.6 & 19.6 \\
\hline & $\mathrm{pH}$ & 7.02 & 6.27 & 5.82 & 6.73 & 6.39 \\
\hline
\end{tabular}

All results are average of three repeated measurements.

having passive ventilation and the structural material addition rose up only to $30^{\circ} \mathrm{C}$ and remained constant for a longer period of time. Temperature rise was not significant in the control reactor with passive (natural) ventilation, but it kept a few degrees higher than room temperature $\left(20 \pm 1{ }^{\circ} \mathrm{C}\right)$. The temperature rise in the reactors shows that in all the cases it was mezophilic processes. Reactor with air supply needed more frequent irrigation, because the moisture evaporated because of the forced ventilation.

At the beginning of the composting process, when the population of microorganisms grows and temperature of the compost mixture rises, easily degradable compounds are decomposed. Emitted heat raises the temperature of the compost mixture but pathogens are not eliminated. After 4 weeks when temperature of the compost mixture fell, additional air supply was discontinued and the compost matured further at mezophilic temperature.

Three compost mixtures were treated with heat at $70 \pm 1{ }^{\circ} \mathrm{C}$ for 12 hours for the reduction of pathogens after 4 weeks of experiment. According to literature data almost all the pathogens are neutralized in this temperature after 1 hour (Haug 2000). Bacterial preparation microbes were not found in the compost mixtures as well. There

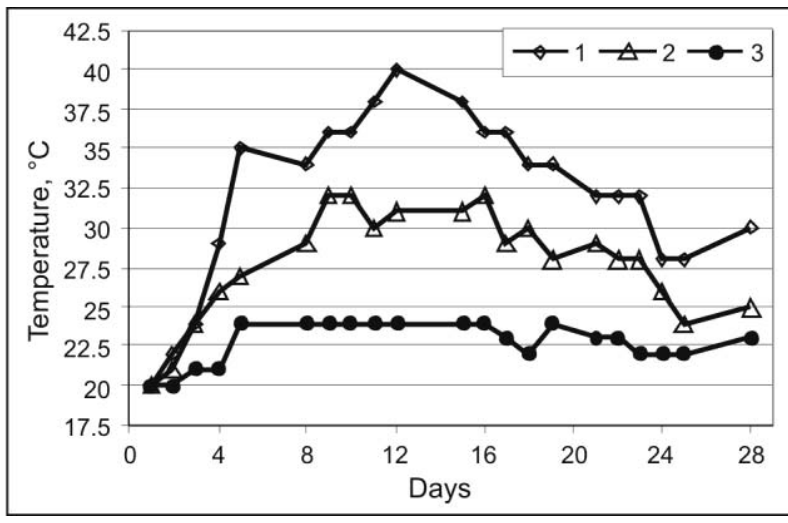

Fig. 3. Temperature of compost and environment (curve 1 - in reactor 1 ; curve 2 - in reactor 2 ; curve 3 - in reactor 3 (control))

have not been found bacterial compositions forming microorganisms as well. The demand of re-spraying the bacterial composition into the compost mixture in the mezophilic stage of the compost maturation is obvious. The duration of thermophilic phase must be at least 2 weeks, and maintaining the temperature of compost at $55{ }^{\circ} \mathrm{C}$ is essential for the application of this technology to the composting sites (Erhan and Kleiman 1997). 
Biodegradation process was very slow and fat content reduced from $10 \%$ to $6.21 \%$ after 12 weeks with no addition of selected microbial strains and structural material (Table 3). This indicates that wild microflora was able to degrade fatty contaminants at some degree. This reactor had the most unpleasant smell. The smallest drop of $\mathrm{pH}$ and the smallest temperature rises was detected in the third reactor indicating a low intensity of fat pollutants degradation processes.

Selected bacterial strains preparations were used in the first and second reactors to accelerate fat degradation process. Comparing contents of degraded fats in the first and second reactors the first reactor with additional aeration had more decomposed fatty pollutants.

The optimal $\mathrm{pH}$ for microorganisms involved in composting process is 5.5 to 8.5 . Microorganisms forming bacterial composition effectively degrade fatty waste at the $\mathrm{pH}$ ranging from 6.3 to 7.5 . When microorganisms fragment fatty substances, organic acids appear which reduces the compost $\mathrm{pH}$ to 4.5 and below. The activity of microorganisms is slowed down this way, so compost mixture $\mathrm{pH}$ is maintained in required level with calcium carbonate.

Sharper fall in $\mathrm{pH}$ of the compost mixture, greater amount of emitted energy at the time of biodegradation indicates that the process was more intensive than in the second reactor. It should be noted that these composting reactors almost had no unpleasant odor, and after 4 weeks of composting the mixture corresponded to the smell of compost. According to the developed technology, composted mixtures must be moved to piles for further maturing after thermophilic and mezophilic stage.

Composting process does not stop at a certain point. Compost is stable and can be used after 12-13 weeks of active composting, but the composted material is further being decomposed. $\mathrm{C} / \mathrm{N}$ ratio of $18.6 / 1$ after 12 weeks was determined in the compost mixture of the first reactor; the third reactor had the $\mathrm{C} / \mathrm{N}$ ratio of $60 / 1$. It shows the compost is not yet fully formed after 12 weeks of composting. Subsequent compost maturation process continues aerobically degrade resistant materials and compounds. Various invertebrates (protozoa, nematodes, earthworms, insect larvae etc.) at this stage are actively involved in compost ripening process. Compost can mature an indefinite period of time. In many cases, the degree of maturation of compost and composting process end is associated with its physical characteristics - the smell, texture, oxygen consumption, $\mathrm{pH}, \mathrm{C} / \mathrm{N}$ ratio.

\subsection{Composting technology optimization}

The third series of composting experiments was carried out to define optimum composting conditions of fat contaminated soil. Measured temperatures of 16 compost mixtures were higher than room temperature in the all cases. The number of live microorganisms was set and the ammonium nitrogen and phosphorus content variation was registered (Tables 4 and 5) during the composting process.
Table 4. Change in the number of microorganisms during composting

\begin{tabular}{|c|c|c|c|c|c|c|}
\hline \multirow[b]{2}{*}{ 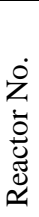 } & \multicolumn{6}{|c|}{ Cell concentration, $\mathrm{CFU} \mathrm{g}{ }^{-1}$} \\
\hline & $\begin{array}{l}\frac{\theta}{\Delta} \\
\frac{d}{3} \\
0\end{array}$ & $\begin{array}{l}\frac{\tilde{v}}{8} \\
\dot{d} \\
\stackrel{N}{N}\end{array}$ & $\begin{array}{l}\ddot{\Delta} \\
\mathbb{\Xi} \\
\vdots \\
\sigma\end{array}$ & $\begin{array}{l}\frac{n}{8} \\
\frac{d}{3} \\
0\end{array}$ & $\begin{array}{l}\frac{n}{\Delta} \\
\vdots \\
\infty\end{array}$ & $\begin{array}{l}\frac{n}{0} \\
\stackrel{0}{3} \\
0\end{array}$ \\
\hline 1 & $1.1 \cdot 10^{9}$ & $1.5 \cdot 10^{6}$ & $6.5 \cdot 10^{7}$ & $8.7 \cdot 10^{6}$ & $1.5 \cdot 10^{6}$ & $0.9 \cdot 10^{6}$ \\
\hline 2 & $1.1 \cdot 10^{9}$ & $2.2 \cdot 10^{6}$ & $3.2 \cdot 10^{7}$ & $6.0 \cdot 10^{5}$ & $2.2 \cdot 10^{6}$ & $1.4 \cdot 10^{6}$ \\
\hline 3 & $1.1 \cdot 10^{7}$ & $1.5 \cdot 10^{7}$ & $2.5 \cdot 10^{7}$ & $5.8 \cdot 10^{6}$ & $1.5 \cdot 10^{7}$ & $8.9 \cdot 10^{6}$ \\
\hline 4 & $1.1 \cdot 10^{7}$ & $8.7 \cdot 10^{6}$ & $5.0 \cdot 10^{6}$ & $2.0 \cdot 10^{6}$ & $8.7 \cdot 10^{6}$ & $7.7 \cdot 10^{6}$ \\
\hline 5 & $1.1 \cdot 10^{9}$ & $1.1 \cdot 10^{7}$ & $7.1 \cdot 10^{6}$ & $9.5 \cdot 10^{6}$ & $1.1 \cdot 10^{7}$ & $9.3 \cdot 10^{6}$ \\
\hline 6 & $1.1 \cdot 10^{9}$ & $1.3 \cdot 10^{8}$ & $1.6 \cdot 10^{8}$ & $7.0 \cdot 10^{6}$ & $1.3 \cdot 10^{8}$ & $7.9 \cdot 10^{7}$ \\
\hline 7 & $1.1 \cdot 10^{7}$ & $1.5 \cdot 10^{7}$ & $1.5 \cdot 10^{7}$ & $2.4 \cdot 10^{6}$ & $1.5 \cdot 10^{7}$ & $0.7 \cdot 10^{7}$ \\
\hline 8 & $1.1 \cdot 10^{7}$ & $2.1 \cdot 10^{7}$ & $1.1 \cdot 10^{7}$ & $6.4 \cdot 10^{6}$ & $2.1 \cdot 10^{7}$ & $1.6 \cdot 10^{7}$ \\
\hline 9 & $1.1 \cdot 10^{8}$ & $3.4 \cdot 10^{7}$ & $2.2 \cdot 10^{7}$ & $8.7 \cdot 10^{6}$ & $3.4 \cdot 10^{7}$ & $9.2 \cdot 10^{6}$ \\
\hline 10 & $1.1 \cdot 10^{8}$ & $9.3 \cdot 10^{6}$ & $8.2 \cdot 10^{6}$ & $1.2 \cdot 10^{6}$ & $9.3 \cdot 10^{6}$ & $4.8 \cdot 10^{6}$ \\
\hline 11 & $1.1 \cdot 10^{9}$ & $5.0 \cdot 10^{7}$ & $2.3 \cdot 10^{7}$ & $1.1 \cdot 10^{7}$ & $5.0 \cdot 10^{7}$ & $2.0 \cdot 10^{7}$ \\
\hline 12 & $1.1 \cdot 10^{7}$ & $1.3 \cdot 10^{7}$ & $1.3 \cdot 10^{7}$ & $6.0 \cdot 10^{6}$ & $1.3 \cdot 10^{7}$ & $8.3 \cdot 10^{6}$ \\
\hline 13 & $1.1 \cdot 10^{8}$ & $9.1 \cdot 10^{6}$ & $9.0 \cdot 10^{6}$ & $1.5 \cdot 10^{6}$ & $9.1 \cdot 10^{6}$ & $5.3 \cdot 10^{6}$ \\
\hline 14 & $1.1 \cdot 10^{8}$ & $3.4 \cdot 10^{7}$ & $4.3 \cdot 10^{7}$ & $6.7 \cdot 10^{6}$ & $3.4 \cdot 10^{7}$ & $9.6 \cdot 10^{6}$ \\
\hline 15 & $1.1 \cdot 10^{8}$ & $1.7 \cdot 10^{7}$ & $2.7 \cdot 10^{7}$ & $4.4 \cdot 10^{6}$ & $1.7 \cdot 10^{7}$ & $1.1 \cdot 10^{7}$ \\
\hline 16 & $1.1 \cdot 10^{8}$ & $1.4 \cdot 10^{7}$ & $2.4 \cdot 10^{7}$ & $1.8 \cdot 10^{6}$ & $1.4 \cdot 10^{7}$ & $0.9 \cdot 10^{7}$ \\
\hline
\end{tabular}

A visible reduction in the quantity of microorganisms in composting boxes, where the initial concentration of the mixture of fat was $12.5 \%$ and $20 \%$ was observed after 2 weeks. Microorganisms require a long adaptation period because fat is heavily degradable substrate. After the adaptation period lipolytic activity arises and fat degradation as well. The maximum fall in $\mathrm{pH}$ was detected in the same compost boxes. We can see in Table 5 and Table 6 the decrease of ammonium, orthophosphate and fat content in the same compost boxes indicating the ongoing life processes. The mathematical model for approximation the dependence of the fat degradation rate on the composition of composting mixture (response surface) was developed using the experimental design plan presented in Table 2 and the corresponding experimental data of fat degradation after 2 weeks presented in Table 6.

The second-order multiple polynomial model demonstrates an adequate approximation of the response surface over the investigated region of the factor variations:

$$
\begin{aligned}
& Y=a_{0}+a_{1} x_{1}+a_{2} x_{2}+a_{3} x_{3}+a_{4} x_{1}^{2}+a_{5} x_{2}^{2}+a_{6} x_{3}^{2}+ \\
& a_{7} x_{1} x_{2}+a_{8} x_{1} x_{3}+a_{9} x_{2} x_{3},
\end{aligned}
$$

where $Y$ is predicted response (percentage of degraded fat), $x_{1}$ is percentage of fat mixture, $\%, x_{2}$ is cell concentration of bacterial composition, CFU/g, $x_{3}$ is percentage of peat, $\%, a_{i}$ are the model parameters identified using the least squares method (Montgomery 2001) for normalized factor variation ranges $\left(-1 \leq x_{i} \leq 1\right), a_{0}=17.3$, $a_{1}=-21.9, \quad a_{2}=7.33, \quad a_{3}=0.47, \quad a_{4}=7.62$, $a_{5}=12.0, \quad a_{6}=-8.88, \quad a_{7}=-7.19, \quad a_{8}=1.62$, $a_{9}=-0.732$. 
Table 5. Ammonium nitrogen and phosphorus content evolution during composting

\begin{tabular}{|c|c|c|c|c|c|c|c|c|c|c|c|c|}
\hline \multirow{3}{*}{ 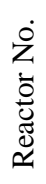 } & \multicolumn{12}{|c|}{ Results of experiments } \\
\hline & \multicolumn{2}{|c|}{0 weeks } & \multicolumn{2}{|c|}{2 weeks } & \multicolumn{2}{|c|}{4 weeks } & \multicolumn{2}{|c|}{6 weeks } & \multicolumn{2}{|c|}{8 weeks } & \multicolumn{2}{|c|}{16 weeks } \\
\hline & \begin{tabular}{|c|}
$\mathrm{NH}_{4}{ }^{+}-\mathrm{N}$ \\
$\mathrm{mg} / \mathrm{kg}$
\end{tabular} & $\begin{array}{c}\mathrm{PO}_{4}{ }^{3-}-\mathrm{P} \\
\mathrm{mg} / \mathrm{kg}\end{array}$ & $\begin{array}{c}\mathrm{NH}_{4}{ }^{+}-\mathrm{N} \\
\mathrm{mg} / \mathrm{kg}\end{array}$ & $\begin{array}{c}\mathrm{PO}_{4}{ }^{3-}-\mathrm{P} \\
\mathrm{mg} / \mathrm{kg}\end{array}$ & $\begin{array}{c}\mathrm{NH}_{4}{ }^{+}-\mathrm{N} \\
\mathrm{mg} / \mathrm{kg}\end{array}$ & $\begin{array}{c}\mathrm{PO}_{4}{ }^{3-}-\mathrm{P} \\
\mathrm{mg} / \mathrm{kg}\end{array}$ & $\begin{array}{c}\mathrm{NH}_{4}{ }^{+}-\mathrm{N} \\
\mathrm{mg} / \mathrm{kg}\end{array}$ & $\begin{array}{c}\mathrm{PO}_{4}{ }^{3-}-\mathrm{P} \\
\mathrm{mg} / \mathrm{kg}\end{array}$ & $\begin{array}{c}\mathrm{NH}_{4}{ }^{+}-\mathrm{N} \\
\mathrm{mg} / \mathrm{kg}\end{array}$ & \begin{tabular}{|c|}
$\mathrm{PO}_{4}{ }^{3-}-\mathrm{P}$ \\
$\mathrm{mg} / \mathrm{kg}$
\end{tabular} & $\begin{array}{c}\mathrm{NH}_{4}{ }^{+}-\mathrm{N} \\
\mathrm{mg} / \mathrm{kg}\end{array}$ & $\begin{array}{c}\mathrm{PO}_{4}{ }^{3-}-\mathrm{P}, \\
\mathrm{mg} / \mathrm{kg}\end{array}$ \\
\hline 1 & 415.9 & 295.6 & 177.6 & 207.8 & 138.4 & 91.9 & 91.9 & 138.2 & 86.3 & 99.3 & 91.6 & 68.1 \\
\hline 2 & 154.3 & 61.8 & 106.9 & 50.6 & 84.0 & 41.8 & 41.8 & 39.9 & 15.4 & 34.3 & 20.3 & 20.9 \\
\hline 3 & 428.6 & 293.8 & 377.3 & 269.2 & 285.8 & 97.2 & 97.2 & 627.3 & 100.3 & 545.6 & 104.3 & 342.5 \\
\hline 4 & 162.6 & 147.3 & 116.4 & 60.2 & 42.9 & 53.5 & 43.5 & 23.0 & 55.7 & 19.4 & 51.8 & 11.6 \\
\hline 5 & 318.7 & 297.4 & 200.1 & 262.8 & 113.0 & 27.8 & 27.9 & 38.1 & 23.8 & 22.6 & 24.2 & 14.8 \\
\hline 6 & 159.5 & 163.7 & 105.2 & 49.4 & 59.2 & 13.7 & 13.7 & 15.1 & 15.5 & 13.9 & 14.8 & 7.62 \\
\hline 7 & 418.3 & 159.2 & 280.9 & 171.5 & 116.8 & 78.0 & 78.0 & 177.9 & 63.9 & 156.9 & 51.3 & 106.9 \\
\hline 8 & 272.4 & 151.3 & 109.0 & 133.7 & 46.1 & 15.9 & 15.9 & 81.2 & 13.3 & 77.6 & 8.62 & 28.6 \\
\hline 9 & 435.1 & 278.9 & 368.3 & 752.8 & 230.2 & 31.4 & 31.4 & 266.4 & 30.4 & 249.5 & 27.8 & 176.3 \\
\hline 10 & 371.6 & 241.3 & 91.5 & 150.0 & 27.0 & 19.0 & 19.0 & 26.2 & 15.2 & 19.4 & 7.65 & 9.32 \\
\hline 11 & 364.3 & 238.9 & 129.8 & 362.0 & 71.4 & 57.1 & 57.1 & 114.2 & 10.7 & 102.5 & 14.7 & 95.3 \\
\hline 12 & 379.2 & 228.7 & 255.6 & 164.8 & 153.5 & 99.1 & 99.1 & 166.6 & 95.2 & 151.4 & 50.5 & 87.4 \\
\hline 13 & 378,3 & 245.3 & 232.7 & 226.3 & 197.5 & 146.6 & 146.6 & 181.0 & 108.3 & 175.9 & 73.2 & 104.1 \\
\hline 14 & 338.1 & 239.4 & 191.1 & 131.8 & 129.4 & 38.6 & 38.6 & 91.5 & 40.3 & 87.5 & 16.7 & 35.2 \\
\hline 15 & 378.6 & 229.8 & 240.5 & 248.4 & 136.7 & 113.1 & 113.1 & 148.1 & 93.6 & 132.2 & 40.1 & 68.2 \\
\hline 16 & 327.8 & 184.9 & 231.5 & 244.3 & 90.0 & 82.3 & 82.3 & 147.1 & 75.2 & 112.1 & 25.4 & 70.2 \\
\hline
\end{tabular}

Table 6. Fat change during composting

\begin{tabular}{|c|c|c|c|c|c|c|c|c|c|c|c|}
\hline \multirow{3}{*}{ 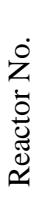 } & \multicolumn{11}{|c|}{ Results of experiments } \\
\hline & \multirow{2}{*}{$\begin{array}{c}0 \text { weeks } \\
\text { FOG } \\
\text { conc., } \\
\%\end{array}$} & \multicolumn{2}{|c|}{2 weeks } & \multicolumn{2}{|c|}{4 weeks } & \multicolumn{2}{|c|}{6 weeks } & \multicolumn{2}{|c|}{8 weeks } & \multicolumn{2}{|c|}{16 weeks } \\
\hline & & $\begin{array}{c}\text { FOG } \\
\text { conc., } \\
\%\end{array}$ & $\begin{array}{c}\text { Redused } \\
\text { FOG, } \\
\%\end{array}$ & $\begin{array}{c}\text { FOG } \\
\text { conc., } \\
\%\end{array}$ & $\begin{array}{c}\text { Redused } \\
\text { FOG, } \\
\%\end{array}$ & $\begin{array}{c}\text { FOG } \\
\text { conc., } \\
\%\end{array}$ & $\begin{array}{c}\text { Redused } \\
\text { FOG, } \\
\%\end{array}$ & $\begin{array}{c}\text { FOG } \\
\text { conc. } \\
, \%\end{array}$ & $\begin{array}{c}\text { Redused } \\
\text { FOG, } \\
\%\end{array}$ & $\begin{array}{c}\text { FOG } \\
\text { conc., } \\
\%\end{array}$ & $\begin{array}{c}\text { Redused } \\
\text { FOG, } \\
\%\end{array}$ \\
\hline 1 & 22.2 & 21.0 & 5.38 & 11.9 & 46.5 & 6.80 & 69.4 & 3.73 & 83.2 & 1.86 & 91.6 \\
\hline 2 & 5.56 & 2.08 & 62.5 & 1.33 & 76.0 & 0.59 & 89.3 & 0.05 & 99.2 & 0.01 & 99.8 \\
\hline 3 & 22.2 & 21.2 & 4.48 & 18.4 & 16.9 & 14.8 & 33.2 & 11.1 & 49.9 & 9.64 & 57.5 \\
\hline 4 & 5.56 & 3.52 & 36.6 & 3.23 & 41.9 & 1.57 & 71.8 & 0.67 & 87.9 & 0.32 & 94.2 \\
\hline 5 & 22.2 & 21.6 & 2.72 & 14.8 & 33.5 & 5.73 & 74.2 & 2.46 & 88.9 & 0.87 & 96.1 \\
\hline 6 & 5.56 & 1.66 & 70.1 & 0.58 & 89.6 & 0.40 & 92.7 & 0.12 & 97.9 & 0.05 & 99.1 \\
\hline 7 & 22.2 & 21.6 & 2.63 & 19.8 & 10.7 & 12.0. & 46.0 & 9.44 & 57.5 & 7.03 & 68.4 \\
\hline 8 & 5.56 & 3.47 & 37.5 & 2.05 & 63.1 & 0.71 & 87.1 & 0.39 & 92.9 & 0.20 & 96.4 \\
\hline 9 & 22.2 & 19.6 & 11.9 & 18.3 & 17.5 & 11.0 & 50.7 & 7.56 & 66.0 & 5.67 & 74.5 \\
\hline 10 & 5.56 & 3.35 & 39.8 & 2.34 & 57.8 & 0.97 & 82.5 & 0.32 & 94.3 & 0.14 & 97.5 \\
\hline 11 & 13.9 & 8.74 & 37.1 & 6.28 & 54.8 & 1.30 & 90.6 & 0.29 & 97.9 & 0.02 & 97.0 \\
\hline 12 & 13.9 & 10.6 & 23.3 & 7.99 & 42.5 & 5.92 & 57.4 & 0.27 & 80.3 & 0.08 & 88.9 \\
\hline 13 & 13.9 & 12.0 & 13.7 & 9.14 & 34.2 & 4.54 & 67.3 & 0.18 & 86.9 & 0.06 & 91.6 \\
\hline 14 & 13.9 & 13.2 & 5.00 & 7.89 & 43.2 & 3.40 & 75.5 & 1.21 & 91.3 & 0.07 & 90.3 \\
\hline 15 & 13.9 & 11.9 & 14.3 & 10.3 & 25.9 & 4.23 & 69.5 & 1.87 & 86.5 & 0.03 & 95.2 \\
\hline 16 & 13.9 & 12.1 & 12.5 & 10.1 & 27.2 & 5.06 & 63.6 & 2.14 & 84.6 & 0.04 & 94.3 \\
\hline
\end{tabular}

The model (1) predictions of experimental data at the factorial experiment points are presented in Table 7. The 2 repeated experiments (points 15, 16 in Table 7) were carried out for testing the model adequacy.

The hypothesis concerning the adequacy of model (1) was verified with the F (Fisher) statistic (Myers and Montgomery 2002). The computed value of the F-statistic $F=27.2$ is less than the critical value $F_{v 1, v 2, \alpha}=F_{5,1,0.05}=230.2$, therefore, the established model (1) for prediction the percentage of degraded fat is satisfactory.

The response surface model (1) based analysis has shown that the predicted maximum rate of fat degradation (over $73 \%$ after 2 weeks of composting) is obtained at the following technological conditions: the fat content $5.0 \%$, cell concentration in bacterial compositions $10^{9} \mathrm{CFU} / \mathrm{g}$, peat content $-9.5 \%$. A character of the response surface (dependence of the fat degradation rate on the investigated factors) in the vicinity of the predicted maximum percentage point is shown in Fig. 4 by contour plots of the response surface sectional views calculated at the maximum percentage point.

The presented response surface shows that the percentage degradation rate of fat increases with decreasing the initial fat concentration: by decreasing the initial concentration from $20 \%$ to $5 \%$ (at peat content $9.5 \%$ and cell concentration $10^{9} \mathrm{CFU} / \mathrm{g}$ ) the percentage degradation rate rises up to 4 times. 
Table 7. Model predictions of experimental data

\begin{tabular}{c|c|c}
\hline $\begin{array}{c}\text { Number of experim- } \\
\text { nent point in Table 3 }\end{array}$ & $\begin{array}{c}\text { Experimental } \\
\text { results }\end{array}$ & $\begin{array}{c}\text { Model } \\
\text { predictions }\end{array}$ \\
\hline 1 & 5.38 & 7.5 \\
2 & 62.5 & 62.6 \\
3 & 4.48 & 8.73 \\
4 & 36.6 & 35.0 \\
5 & 2.72 & 4.82 \\
6 & 70.1 & 66.3 \\
7 & 2.63 & 3.08 \\
8 & 37.5 & 35.8 \\
9 & 11.9 & 2.94 \\
10 & 39.8 & 46.8 \\
11 & 37.1 & 36.6 \\
12 & 23.3 & 21.9 \\
13 & 13.7 & 8.86 \\
14 & 5.00 & 7.91 \\
15 & 14.3 & 17.3 \\
16 & 12.5 & 17.3 \\
\hline
\end{tabular}
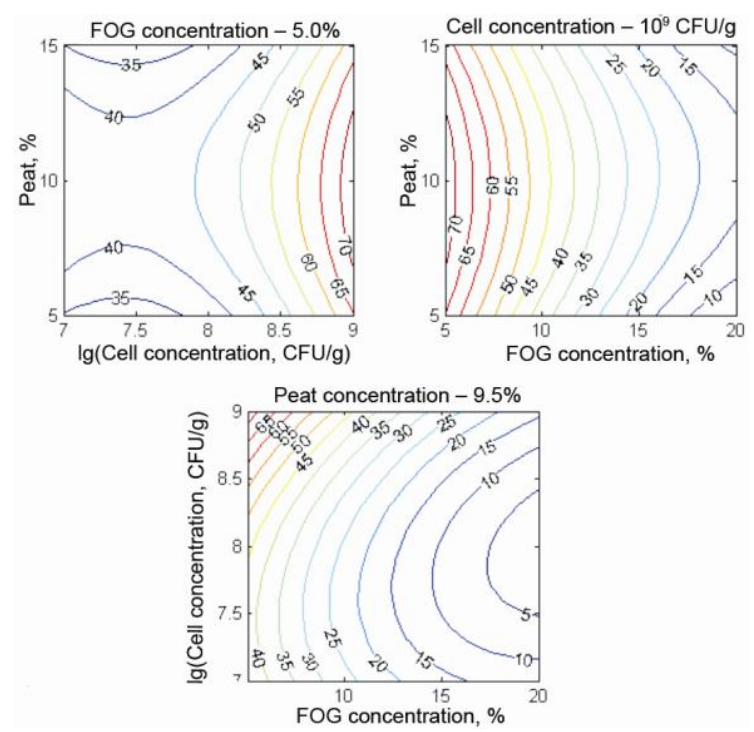

Fig. 4. Dependence of the degraded fat percentage after 2 weeks on the composition of composting mixture (percentage of fat, inoculate cell concentration and the percentage of peat) in the vicinity of maximum degraded fat percentage point

However, in economic terms it is reasonable to treat the compost with higher initial percentage of fat, at which the higher degradation rate over a longer period of time can be achieved in terms of absolute units. At the initial fat concentration $20 \%$ in 6 weeks about $70 \%$ of total fat was degraded.

\subsection{Concentrated fatty waste disposal site prototype}

Concentrated fat waste disposal site prototype is designed (Fig. 5). The site is designed on rolled ground with $10 \mathrm{~cm}$ of sorbent on the bottom. Compost mixture containing structural material and added bacteria is placed into the closed container with air, bacterial composition and water supply, temperature regulation. The $1^{\text {st }}$ phase of composting lasts $1-3$ months. The compost mixture is maintained in thermophilic conditions for the last 2 weeks of treatment to ensure the sanitary-hygienic requirements.

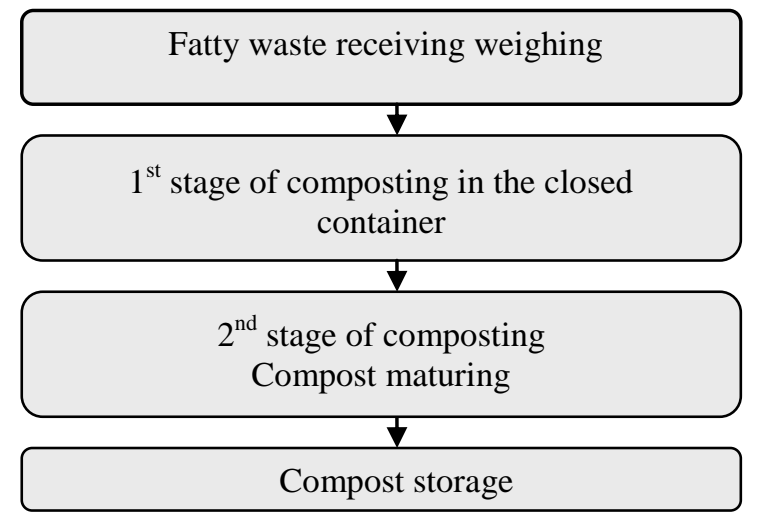

Fig. 5. Concentrated fatty-waste disposal site prototype

At the end of the first phase composting mixture is transferred to the open composting piles. In the second stage compost maturates in mezophilic conditions for indeterminate period of time. Composting pile height is $1.2-1.5 \mathrm{~m}$, the base width is about $2.5-3.0 \mathrm{~m}$, the sides have small rake in order the pile would get narrower to the top and would have the shape of trapezium in the cross-section and the top width would be $0.6-1.0 \mathrm{~m}$. Pile length is 5-6 meters. Composting piles must be mixed 3 4 times during the composting season to access sufficient quantities of oxygen, to get inner and outer layers humidity and fragmentation equal, and to accelerate composting process. Process monitoring consists of regular compost temperature, quantity of microorganisms, $\mathrm{pH}$ and moisture measurements, and control tests of samples.

Compost mixture loses about $30-40 \%$ of former organic materials in carbon dioxide and water form, therefore the yield of compost represents only $40-50 \%$ of the initial volume of compost, and up to a half its initial mass.

Total duration fat waste composting time is 1.0 to 1.5 years. Obtained product is compost, which can be divided into two types. Compost with low-nutrient content can be used for improving soil structure. Compost with enough nutrient's content, can be used as fertilizer in the soil, to supply the plants with the necessary basic nutrients and organic materials. High-quality compost can be used for market needs: in horticulture, gardening, landscape development and agriculture, when the need to improve soil structure exists.

\section{Conclusions}

Technology of waste with high fat content was developed. The waste is blended with the structural material, sprayed with bacterial composition and enriched with feed elements.

Optimal conditions and composition of composting mixture is determined: the initial fat content $-5 \%$, the concentration of bacterial composition's cells $109 \mathrm{CFU} / \mathrm{g}$, the quantity of structural materials $-9.5 \%$.

Concentrated fat waste disposal site prototype is designed. Maximal possible fat concentration for this composting technology is $20 \%$ and depends on initial waste concentration, and lasts 1 to 1.5 years. 


\section{Acknowledgments}

This investigation is supported by the Agency for International Science and Technology Development Programmes in Lithuania under Eureka Project E!3726.

\section{References}

Adewumi, I. K.; Ogedengbe, M. O.; Adepetu, J. A.; Aina, P. O. 2005. Aerobic composting of municipal solid wastes and poultry manure, Journal of Applied Sciences Research 1(3): 292-297.

Agamuthu, P. 1994. Composting additives for of goat dung with various improved fertilizer capacity, World Journal of Microbiology \& Biotechnology 16: 194-198. doi:10.1007/BF00360886

Alef, K.; Nannipieri, P. (Eds.). 1995. Methods in Aplied Soil Microbiology and Biochemistry. London: Academic Press, Harcourt Brace\& Company. 578 p.

Bazrafshan, E.; Zazouli, M.; Bazrafshan, J.; Bandpey, A. M. 2006. Co-composting of Dewatered Sewage Sludge with Sawdust, Pakistan Journal of Biological Sciences 9(8): 1580-1583. doi:10.3923/pjbs.2006.1580.1583

Chipasa, K. B.; Mędrzycka, K. 2006. Behavior of lipids in biological wastewater treatment processes, Journal of Industrial Microbiology \& Biotechnology 33: 635-645. doi:10.1007/s10295-006-0099-y

Coker, C. 2006. Composting grease trap wastes, BioCycle 47(8): 27-31.

Das, K. C.; Minkara, M. Y.; Melear, N. D.; Tollner, E. W. 2002. Effect of poultry litter amendment on hatchery waste composting, J. Appl. Poult. Res. 11: 282-290.

EC directive 2006/12/EB on the landfill of waste, $O L L 114$, 2006-04-27.

Erhan, S. M.; Kleiman, R. 1997. Biodegradation of estolides from monounsaturated fatty acids, J Am Oil Chem Soc. 74: 605-607. doi:10.1007/s11746-997-0189-7

Gandhi, N. N. 1997. Applications of lipases, Journal of the American Oil Chemists' Society (JAOCS) 74: 621-634.

Gea, T.; Artola, A.; Sánchez, A. 2004. Co-composting sewage sludge and fats. Optimal ratios and process evolution. Sustainable Organic Waste Management for Enviromental Protection and Food Safety, in Organic Waste Treatments: Safety Implications, 223-228.

Grigiškis, S.; Čipinyte, V.; Baškys, E.; Celiešiūtè, R. 2007. Selection of biological agents for the cleaning up grease contaminated environment, in International conference Eco-Balt'2007, May 10-11, Riga, Latvia, 115.

Gunstone, F. D.; Padley, B. F. 1997. Lipid Technologies and Applications. CRC Press. 834 p. ISBN 0824798384, 9780824798383.

Hartmann, K.; Lezki, E.; Schafer, W. 1974. Statistische Versuchsplanung und Auswertung in der Stoffwirtschaft. VEB Deutscher Verlag fur Grundstoffindustrie, Leipzig. 444 p.

Haug, R. T. 2000. The practical Handbook of Compost Engeneering. USA: Lewis publishers. $717 \mathrm{p}$.

Levišauskas, D.; Tekorius, T.; Čipinytè, V.; Grigiškis, S. 2004. Experimental optimization of nutrient media for cultivation of Arthrobacter bacteria, Latvian Journal of Chemistry (1): 75-80. ISSN 0868-8249.

LST ISO 10390:2005. Dirvožemio kokybè. pH nustatymas [Soil quality - Determination of $\mathrm{pH}] .7 \mathrm{p}$.

Mendes, A. A.; Castro, H. F. 2005. Effect on the Enzymatic Hydrolysis of Lipids from Dairy Wastewater by Replacing Gum Arabic Emulsifier for Sodium Chloride, Brazilian Archives of Biology and Technology 48(Special No.): 135-142.

Montgomery, D. C. 2001. Design and Analysis of Experiments. John Wiley\&Sons.

Myers, R. H.; Montgomery, D. C. 2002. Responce Surface Methodology. Process and Product Optimization Using Designed Experiments. John Wiley \& Sons. 798 p.

Nakasaki, K. 2004. Degradation of fats during thermophilic composting of organic waste, Waste Management \& Research 22(4): 276-282. doi:10.1177/0734242X04045430

Navickas, K.; Župerka, V.; Venslauskas, K. 2007. Gyvūninės kilmès šalutinių produktų anaerobinis perdirbimas ị biodujas [Anaerobic treatment of animal by-products to biogas], $L \check{L} \bar{U} U \check{Z} \bar{U} I$ Instituto ir $L \check{Z} \bar{U}$ Universiteto mokslo darbai 39(4): 60-68.

Saifuddin, N.; Chuna, K. H. 2006. Biodegradation of lipid-rich waster by combination of microwawve irradiation and lipaze immobilized on chitosan, Biotechnology 5(3): 315-323. doi:10.3923/biotech.2006.315.323

Tremier, A.; Guardia, A.; Martel, J. 2004. J. L. Improving composting treatment through modeling: conception of an invessel composting model, in Sustainable Organic Waste Management for Environmental Protection and Food Safety. Organic Waste Treatments: Safety Implications, 239-242.

\section{RIEBALINIŲ ATLIEKŲ KOMPOSTAVIMO TECHNOLOGIJOS SUKŪRIMAS NAUDOJANT LIPAZINIO AKTYVUMO BAKTERINI PREPARATĄ}

\section{J. Aikaitė-Stanaitienė, S. Grigiškis, D. Levišauskas, V. Čipinytė, E. Baškys, V. Kačkytė}

Santrauka

UAB „Biocentre“ sukurta nauja riebalais užterštų atliekų kompostavimo technologija, pagrịsta riebalus oksiduojančių mikroorganizmų panaudojimu. Ši technologija pažangesnè taršos prevencijos požiūriu, jos privalumas - švaresnè gamyba. Sukurtoji technologija atitinka griežtus aplinkos apsaugos ir higienos reikalavimus. Tyrimai atlikti laboratorinemis sąlygomis. Riebalinių atliekų kompostavimo procesų technologiniams parametrams optimizuoti taikyta faktoriniais eksperimentais grịsta reakcijos paviršiaus analizès metodologija. Nustatyta optimali eksperimentinè kompostuojamo mišinio sudètis: pradinis riebalų kiekis - 5\%, biopreparato ląstelių koncentracija $-10^{9} \mathrm{KSV} / \mathrm{g}$, struktūrinès medžiagos kiekis $9,5 \%$. Padidinus pradinę riebalų koncentraciją nuo $5 \%$ iki $20 \%$, riebalų skaidymo sparta sulètejja apie 3 kartus. Suprojektuotas koncentruotų riebalinių atliekų utilizavimo aikštelès modelis. Kompostavimo proceso trukmè 1-1,5 metų.

Reikšminiai žodžiai: taukai, aliejus ir lajus, kompostavimas, biopreparatas, biodegradacija, matematinis modeliavimas, optimizacija. 


\title{
РАЗРАБОТКА ТЕХНОЛОГИИ КОМПОСТИРОВАНИЯ СИЛЬНОЗАГРЯЗНЕННЫХ ЖИРОСОДЕРЖАЩИХ ОТХОДОВ С ИСПОЛЬЗОВАНИЕМ БАКТЕРИАЛЬНОГО ЛИПОЛИТИЧЕСКОГО ПРЕПАРАТА
}

\author{
Й. Айкайте-Станайтене, С. Григишкис, Д. Левишаускас, В. Чипините, Э. Башкис, В. Качките \\ Резюме
}

В 3 AO “Biocentras” была создана новая технология компостирования отходов с высоким содержанием жира. Технология компостирования загрязненных жирами отходов основана на использовании микроорганизмов, окисляющих жиросодержащие вещества. Разработанная технология является привлекательной для более чистого производства/предупреждения загрязнения окружающей среды, а также удовлетворяет строгим экологическим и гигиеническим требованиям. Исследован процесс компостирования. Для оптимизации процесса применен метод математического моделирования. Опыты проведены в лабораторных условиях. Определен оптимальный состав смеси: начальное содержание жира $-5 \%$, концентрация бактериальных клеток в препарате $-10^{9} \mathrm{KOE} / г$, количество структурных материалов - 9,5\%. Деградация жиров замедляется в 3 раза, если первоначальная концентрация жиров увеличивается от $5 \%$ до $20 \%$. Разработан и построен прототип площадки для компостирования жировых отходов. Процесс компостирования длится от 1 до 1,5 лет.

Ключевые слова: жиры, растительные и животные масла, компостирование, бактериальный препарат, биоразложение, математическое моделирование, оптимизация.

Jolanta AIKAITE்-STANAITIENE். Dr, head of Laboratory of Chemistry, JSC "Biocentras", Vilnius. Doctor of Physical Sciences, Vilnius Institute of Chemistry, 2004. Publications: author of 9 scientific publications, participant of over 5 international conferences. Research interests: ecology, ecological biotechnology, environmental protection.

Saulius GRIGIŠKIS. Dr, director of JSC “Biocentras”, Vilnius. Doctor of Science, Moscow Institute of Technology of Food Industry, 1983. Publications: author of over 50 scientific papers, participant of over 40 international and national conferences. Research interests: microbiology, ecological biotechnology, ecology.

Donatas LEVIŠAUSKAS. Dr Habil of Technological Sciences (informatics engineering), Kaunas University of Technology, 1999. Doctor of Technological Sciences (informatics engineering), Kaunas University of Technology, 1981. Publications: author of over 130 scientific publications, participant of over 50 conferences. Research interests: mathematical modeling, optimization and control of biotechnological processes.

Vilma ČIPINYTĖ. Dr, head of Laboratory of Microbiology, JSC "Biocentras", Vilnius. Doctor of Science, Vilnius Institute of Biotechnology, 2000. Publications: co-author of 10 scientific papers, participant of over 5 international and national conferences. Research interests: microbiology, ecological biotechnology.

Egidijus BAŠKYS. Dr, director of research, JSC "Biocentras”, Vilnius. Doctor of Biological Sciences, 1978. Publications: author of over 50 scientific papers, participant of over 40 international and national conferences. Research interests: microbial metabolism, optimization of biotechnological process and ecology.

Vaiva KAČKYTĖ. Master student (environmental engineering), Faculty of Environmental Engineering, Vilnius Gediminas Technical University (VGTU). 